\title{
Tomasz Róg
}

Państwowa Wyższa Szkoła Zawodowa, Pita

\section{O ŹRÓDŁACH MOTYWACJI W KONTEKŚCIE EDUKACJI JĘZYKOWEJ DOROSŁYCH}

\begin{abstract}
This paper concerns the teaching of foreign languages to adults with special attention given to the concept of motivation. The present author wishes to present the findings of his small-scale research done on a group of adults and their teachers as regards the sources of motivation in the context of adult language instruction. To begin with, an overview of the notion of motivation is followed by its typology and current state of knowledge about teaching languages to adults is briefly outlined. The second part of the article demonstrates the procedure and results of the study.
\end{abstract}

\section{Wprowadzenie}

Artykuł podejmuje próbę wyjaśnienia powodów, dla których dorośli rozpoczynają lub kontynuuja naukę języka obcego. Tym samym, autor stawia pytania o to, co motywuje ich do uczenia się języków obcych, co sprawia im największą satysfakcję, a co jest przyczyną trudności. Szukając odpowiedzi, autor postanowił zaczerpnąć informacji z dwóch źródeł: od dorosłych uczących się na kursach językowych i od ich nauczycieli. Pierwsza część artykułu stanowi tło teoretyczne dla przeprowadzonego badania. $Z$ racji ograniczeń edytorskich, część ta zarysowuje jedynie problematykę motywacji. Autor skupia się w niej na różnych perspektywach postrzegania motywacji, przywołuje popularną klasyfikację motywacji i odnosi się do zagadnienia uczenia dorosłych. W drugiej części przytoczone są wyniki badania przeprowadzonego wśród dorosłych uczących się języków angielskiego i niemieckiego.

Niewatpliwie motywacja to jeden z głównych czynników odpowiedzialnych za uczenie się. Uznaje się, że znajduje się ona wśród tak kluczowych zagadnień jak styl uczenia się, zdolności (ang. aptitude) czy wiek (Oxford 2007: 
171). Badania nad motywacją w nauczaniu języków obcych sięgają lat 70-tych (przede wszystkim Gardner i Lambert, 1972), a ich rozkwit przypadł na lata 90te XX wieku (Brown, 1990; Dörnyei, 1990, 1994; Williams i Burden, 1997). Jak twierdzi Chomsky (1988: 181), rolą nauczyciela w 99\% jest rozbudzanie zainteresowania uczniów swoim przedmiotem. Zwiększanie motywacji uczniów do nauki spotyka się jednak z istotnym problemem, jakim jest fakt, że motywacja jest cechą niezwykle indywidualną. Jednocześnie trudno zaprzeczyć, że tak indywidualny czynnik jak motywacja ma poważny wpływ na ewentualny sukces $\mathrm{w}$ nauce języka obcego.

Przyjmuje się, że motywacja to stan wewnętrzny charakteryzujący się siłą mobilizującą organizm do wysiłku na rzecz osiagnięcia konkretnego celu (Figarski, 2003: 100). Indywidualne bodźce składające się na osiagnięcie stanu motywacji z wiekiem stają się coraz bardziej różnorodne, np. w przypadku nauki języków obcych począwszy od uczenia się „dla mamusi” po uczenie się dla osiągnięcia korzyści finansowych. Bodźce te pojawiają się w różnych konfiguracjach, rozwijają się i ewoluują w miarę upływu czasu. Uznaje się również (np. Gardner i MacIntyre, 1993: 2), że oprócz chęci osiagnięcia celu, motywację konstytuują wysiłek włożony w realizację celu oraz satysfakcja z jego osiagnięcia. Dyskusję nad zagadnieniem komplikuje dodatkowo duża ilość zmiennych, które należałoby wziąc pod uwagę definiując motywację. Czynniki takie jak zainteresowania, wrodzona ciekawość, wiek, nauczyciel, środowisko czy ewentualny egzamin z przedmiotu są jednymi z wielu, jakie należałoby rozpatrzyć.

\section{Motywacja - perspektywy badawcze i typy}

$\mathrm{Na}$ przestrzeni ostatnich stu lat, spojrzenie na motywację uwarunkowane było przez dominujący paradygmat psychologiczny. I tak, wyróżniamy trzy główne podejścia do motywacji: behawioralne, kognitywistyczne i konstruktywistyczne. W podejściu behawioralnym główną inspirację stanowiły wnioski z obserwacji zachowań zwierząt w laboratoriach. Te zachowania, mające na celu przede wszystkim zaspokojenie podstawowych potrzeb, stały się źródłem uogólnień, które przenoszono na zachowania ludzkie. Warunkowanie psów, aby śliniły się na dźwięk dzwonka, który kojarzony był z podawaniem jedzenia, prowadziło do wniosków, że ludzie, zwłaszcza w młodym wieku, najlepiej będą się uczyć, gdy zostaną zmotywowani przez nagrodę. Stąd, behawioryzm zakładał, że motywacja w dużej mierze uzależniona jest od czynników zewnętrznych (Williams i Burden, 2007: 113). Patrząc z tej perspektywy, człowiek wykona zadanie, jeśli spotka go za to jakaś nagroda. Teoria ta wyewoluowała później we freudowska nieuświadomioną motywację, tj. założenie, że motywują nas bodźce, których sami sobie nie uświadamiamy (np. chęć bycia lekarzem może być motywowana przez chęć pomagania innym lub przez lęk przed choroba).

Kognitywistyczne spojrzenie na motywację sytuuje ja jako zjawisko odrębne od afektu. Ta kluczowa zasada stanowi jednak źródło problemów, gdyż 
oddzielenie aspektów poznawczych od emocjonalnych wydaje się ryzykowne, biorąc pod uwagę różnorodność bodźców mających wpływ na motywację. W przeciwieństwie do spojrzenia behawioralnego, kognitywizm opiera się na przekonaniu, że bodźce te pochodzą niejako z wewnątrz człowieka. Przyjmuje się, że zarówno za porażki, jak i sukcesy odpowiedzialne są czynniki wewnętrzne takie jak osobowość, samoocena czy wysiłek i to one mają wpływ na zwiększenie bądź obniżenie motywacji. Wszelkie zjawiska zewnętrzne nie mają takiego wpływu (Weiner, 1985: 560). Mając wolną wolę, każdy z nas odpowiada za swoje wybory i ma kontrolę nad własnym uczeniem się.

Główną krytyką kognitywistycznego podejścia do motywacji był brak udziału sfery emocjonalnej i kontekstu społecznego. Te dwa elementy znalazły jednak swoje odbicie w perspektywie konstruktywistycznej, która łączy w sobie zarówno zainteresowanie czynnikami wewnętrznymi, jak i tymi będącymi poza władzą człowieka. W koncepcji konstruktywistycznej zakłada się, że każdy człowiek motywowany jest przez różne bodźce, działające na niego z różna siłą $i$ prowadzące do indywidualnych decyzji. Wśród tych bodźców istotną rolę odgrywa kontekst społeczno-kulturowy jednostki oraz potrzeba samorealizacji (ang. self-actualisation) (Maslow, 2006: 78). W związku z tym, czynniki motywujące będą różne dla różnych osób. W nauczaniu języków obcych, uwagę na to zwrócono w niedawnym badaniu Humphreys i Spratt (2008), gdzie wykazano, że główną motywacją do wyboru języka obcego wśród chińskich studentów był jego wymiar utylitarny, tj. potencjalna użyteczność dla studenta.

Współczesne teorie motywacji, na co zwraca uwagę Michońska-Stadnik (2008: 110), skupiają się na sferze emocjonalnej człowieka. Doświadczenia takie jak wstyd, złość czy lęk, ale również entuzjazm, odwaga i dobre samopoczucie będą miały przemożny wpływ na zapał do nauki języka obcego. Przywołując badania nad mózgiem Schumann (1997) wykazał, w jaki sposób emocje wpływają na proces przyswajania języka obcego. Mechanizmy neurobiologiczne odpowiedzialne za emocje rządzą motywacją człowieka w ogóle, a zatem „brak zaangażowania emocjonalnego ucznia powoduje, że język obcy przyswajany jest jako wiedza deklaratywna" (Michońska-Stadnik, 2008: 112). Paradoksalnie więc, podkreśla Michońska-Stadnik (2008: 115), tworzenie połączeń neuronalnych w mózgu ucznia, poprzez kojarzenie nauki języka z przyjemnościa, jest niczym innym jak warunkowaniem znanym $\mathrm{z}$ behawioryzmu. Powstałe w ten sposób trwałe połączenia w mózgu ucznia mogą sprawić, że będzie on długotrwale zmotywowany.

Popularnym podziałem motywacji jest rozdział na motywację zewnętrzną i wewnętrzną. W przypadku tej pierwszej, główny akcent pada na możliwość otrzymania nagrody bądź uniknięcia kary. W tym założeniu wpływanie na motywację jest poza zasięgiem ucznia. Z kolei mówiąc o motywacji wewnętrznej, mamy na myśli „podniety intelektualne” (Figarski, 2003), które pochodzą od ucznia, a uczenie się jest nagrodą samą w sobie. Korzystniejsza z punktu widzenia nauczyciela jest, zatem motywacja wewnętrzna. Badania potwierdzają (Arnold i Brown, 2005: 14), że orientacja wewnętrzna przynosi większe korzyści 
długoterminowe niż motywacja zewnętrzna (która niemniej stanowi istotny aspekt w procesie dydaktycznym).

Inny podział, zaproponowany przez Gardnera i Lamberta w 1972 r., dzieli motywację na instrumentalną i integracyjną. Motywacja instrumentalna w nauce języka obcego wynika z chęci osiagnięcia zysków, zdobycia lepszej pracy lub zrobienia kariery naukowej - wszystko to umożliwi znajomość języka obcego. Z drugiej strony, gdy powody nauki języka związane są z chęcią poznania obcej kultury i nawiązania nowych znajomości, mówimy o motywacji integracyjnej. Prowadzone badania nie wykazały jednoznacznie, która z tych dwóch motywacji przynosi lepsze efekty w testach zaawansowania językowego (patrz: Lankiewicz, 2010: 113).

\section{Motywacja a wiek dorosły}

Mówiąc o wieku dorosłym, należy pamiętać jak zróżnicowana może to być grupa. Jak wskazuje Zawadzka (2004: 122), dorosły to człowiek pomiędzy 18. a 75. rokiem życia. W związku z tym, różne będą motywy podejmowania przez nich nauki języków obcych. Zanim przyjrzymy się wynikom badania przeprowadzonego przez autora, spójrzmy, co o motywacji dorosłych piszą dydaktycy i psychologowie. Knowles (2009: 182) wyróżnia cztery czynniki mające wpływ na motywację osób dorosłych: chęć odniesienia sukcesu, chęć wpływu na proces uczenia się, poczucie uczenia się czegoś wartościowego i poczucie, że uczenie się sprawia im przyjemność. Z tej perspektywy, motywacja dorosłych ma orientację wewnętrzną oraz zawiera pierwiastek instrumentalny. Większą motywację do nauki można, zatem uzyskać pokazując dorosłym, w jaki sposób mogą zyskać na znajomości języka obcego oraz umożliwiając im wpływ na program kursu.

Korzystając z definicji Marczuka (1994: 72-73), uczeń dorosły to taki, który świadomie podejmuje trud uczenia się i podlega zorganizowanemu działaniu oświatowemu. Uczący się dorosły zwykle różni się od innych uczących się doświadczeniem pracy zawodowej i związanymi z nią obowiązkami i obciążeniami, obowiązkami rodzinnymi, przerwą w edukacji, a co za tym idzie zróżnicowanym stanem wiedzy, ukształtowanym światopoglądem oraz złożonościa warunków socjalnych i organizacyjnych. Aby osiagnąć jak najwyższy stopień motywacji, Marczuk zaleca (1994: 75) dobór jak najróżnorodniejszych treści odpowiadających doświadczeniu dorosłego ucznia. Treści nauczania powinny być w miarę możliwości zindywidualizowane, a jednocześnie dobrane na różne sposoby pod względem ich struktury i logiki. Ponadto, treści te winny posiadać zarówno walory teoretyczne jak i praktyczne. Należy pamiętać, że w związku z wyżej wymienionymi cechami uczniów dorosłych, ich oczekiwania odnośnie procesu edukacyjnego moga być bardzo różne. W przeciwieństwie do uczniów młodszych, podlegających obowiązkowi szkolnemu, dorośli zwykle mają sprecyzowane powody, dla których podejmują naukę.

Podobne spostrzeżenia odnośnie zróżnicowania czynników motywacyjnych wśród dorosłych uczniów czyni Zawadzka (2004: 123). Podkreśla ona, że 
starsi dorośli zwykle podejmują naukę, by realizować swoje pasje, a nierzadko nauka języków obcych i możliwość rozmowy w obcym języku z innymi dorosłymi, ma istotny wpływ na podniesienie samooceny. Często podejmowanie kursów językowych staje się sposobem spędzania czasu wolnego. Po przejściu na emeryturę, starsi dorośli uczęszczają na kurs w celach towarzyskich, poznają nowych ludzi, nawiązują nowe znajomości. Niekiedy nauka języków obcych staje się dla nich źródłem poznania innych krajów i kultur. Dla wielu jest to również trening pamięci. Zawadzka mówi również o motywach snobistycznych, kiedy znajomość języka obcego staje się elementem imponowania przyjaciołom czy znajomym. Dominują również motywy intelektualne, tj. chęć poszerzenia swojej wiedzy wykorzystując w tym celu znajomość języka.

\section{Opis badanych grup}

Badaniem objęto dorosłe osoby uczestniczące w kursach języków obcych (jęz. angielski i niemiecki) na terenie Piły i okolic. W badaniu wzięło udział 60 osób uczących się języka obcego na różnych poziomach zaawansowania, opierając się na Europejskim Systemie Opisu Kształcenia Językowego, były to poziomy pomiędzy A1 a B2. Najmłodsza uczestniczka badania miała 27 lat, najstarsza 63. Średnia wieku badanych wyniosła 42,3 lata. Jedna osoba nie ujawniła swojego wieku. Wśród badanych przeważały kobiety (85\%).

Druga część badania, tj. wywiady z nauczycielami przeprowadzono z czterema osobami, trzema kobietami i mężczyzną uczącymi badanych kursantów. Nauczycielki biorące udział w badaniu posiadają stopień nauczyciela dyplomowanego, zaś mężczyzna to nauczyciel kontraktowy

\section{Cel badania}

Badanie miało na celu przede wszystkim poznanie motywacji badanych do uczenia się języka obcego w dorosłym życiu. Autor postawił pytania dotyczące powodów podejmowania nauki, sposobów wykorzystania nowopoznanej wiedzy oraz zapytał o to, co daje badanym największą satysfakcję z nauki języka. Ponadto, zapytano jakiego typu zadania badani najbardziej lubią wykonywać, a co sprawia im najwięcej trudności. Dodatkowo, respondenci mieli szansę wyrazić swoje oczekiwania co do przebiegu kursu. Celem badań nauczycieli była weryfikacja opinii uczniów z perspektywy nauczających.

\section{Problem badawczy i hipotezy}

Głównym problemem badawczym autora była motywacja dorosłych uczących się języka obcego na kursach językowych, a najważniejszym pytaniem badawczym było: „Co motywuje dorosłe osoby do podejmowania nauki języka obce- 
go"? Opierając się na własnym doświadczeniu pracy jako lektor języka angielskiego, autor badania postawił hipotezę, że większość dorosłych podejmuje kursy językowe głównie z przyczyn instrumentalnych (np. wykorzystanie języka w pracy, możliwość oglądania programów w obcym języku). Odnośnie przebiegu kursu, autor założył, że dorośli uczący się języka najbardziej lubią wykonywać zadania, w których mają szansę przełożyć obce zwroty na język ojczysty, ponieważ czują się wtedy pewniej, niż kiedy operują w przeważającej mierze językiem obcym (jak to ma miejsce w podejściu komunikacyjnym).

\section{Przebieg i analiza badań}

Badanie o charakterze sondażowym przeprowadzono na przełomie listopada $\mathrm{i}$ grudnia 2010 roku w szkołach językowych Piły i okolic. Autor badania przygotował ankiety, które następnie rozdał zaprzyjaźnionym nauczycielom z prośbą o przekazanie ich dorosłym uczniom języka. Ankiety te składały się z pięciu pytań zamkniętych i jednego pytania otwartego. Użycie głównie pytań zamkniętych miało na celu przede wszystkim zachęcenie badanych do wypełnienia ankiety. Pytania otwarte, choć moga dawać lepszy wgląd w opinie badanych i dostarczać precyzyjnych odpowiedzi (Nunan, 2005: 143), bywają jednak odstręczające dla ankietowanych, głównie z powodu większego wysiłku, jaki trzeba włożyć w udzielenie odpowiedzi. Kwestie wymagające głębszej analizy, a które trudno streścić w kilku słowach, lepiej formułować w formie pytań zamkniętych, gdzie badany ma do wyboru kilka różnych odpowiedzi (Wilczyńska i MichońskaStadnik, 2010: 169). Jedyne pytanie otwarte zawarte w ankiecie dotyczyło opisania, w jaki sposób kurs języka mógłby być ulepszony.

Nauczyciele przeprowadzający badanie rozdali ankiety przed rozpoczęciem zajęć i dali kursantom ok. 10-15 minut na ich wypełnienie, po czym ankiety zostały zebrane. Pozwoliło to na ich stuprocentową zwrotność. Ankiety zawierały informację dotyczącą użyteczności badania (tj. na potrzeby artykułu omawiającego kształcenie językowe dorosłych). Jasne komunikowanie celu badania zalecane jest przez badaczy (np. Dörnyei, 2003: 86), gdyż zwiększa to motywację respondentów do wypełnienia ankiet. Zwrócone ankiety poddano analizie statystycznej (za wyjątkiem pytania otwartego, na które odpowiedziało jedynie 43\% respondentów).

\section{Wyniki}

W dalszej części artykułu przedstawione są wyniki badań. Pierwszą część stanowią rezultaty badań przeprowadzonych wśród dorosłych uczących się języka, druga natomiast, wyniki wywiadów przeprowadzonych z ich nauczycielami. 


\subsection{Opinie uczniów}

Badaniem objęto 60 osób (51 kobiet i 9 mężczyzn). 46 osób (76\%) uczy się języka angielskiego, a 14 osób (24\%) języka niemieckiego. Pierwsze pytanie dotyczyło powodów, dla których ankietowani uczą się języka obcego. Spośród 12 zasugerowanych odpowiedzi i odpowiedzi własnych respondentów $60 \%$ wskazało na potrzebę znajomości języka podczas podróży zagranicznych. Drugim najpopularniejszym (50\%) powodem była chęć zrozumienia piosenek i filmów w języku obcym (por. tabela 1$)$.

\begin{tabular}{|l|l|}
\hline język jest potrzebny do porozumiewania się w czasie podróży zagranicznych & $60 \%$ \\
\hline chcę rozumieć piosenki i filmy w języku obcym & $50 \%$ \\
\hline mam znajomych, członków rodziny, którzy mówią w tym języku & $45 \%$ \\
\hline jest to sposób spędzenia wolnego czasu & $40 \%$ \\
\hline chce porozumiewać się z obcokrajowcami & $40 \%$ \\
\hline jest mi potrzebny w pracy & $25 \%$ \\
\hline lubię uczyć się języków obcych & $25 \%$ \\
\hline
\end{tabular}

Tabela 1: Powody nauki języka obcego.

Pojedyncze odpowiedzi wskazywały na chęć wyjazdu za granicę w celach zarobkowych, zainteresowanie kulturą kraju nauczanego języka, chęć rozwijania się jako człowiek, doskonalenia pamięci i jako trening logicznego myślenia.

W drugim pytaniu badani podawali, jakie czynniki związane z nauką obcego języka sprawiają im największą sytuację. Zdecydowana większość respondentów (85\%) uznała, że jest to coraz lepsze rozumienie innych mówiących w języku obcym. Wielu (75\%) było również zadowolnych z coraz większego zasobu słownictwa. Dwie osoby odpowiedziały, że czytają książki w języku obcym. Tylko jedna osoba wskazała, że satysfakcję sprawia jej oglądanie filmów w języku obcym (por. tabela 2).

\begin{tabular}{|l|c|}
\hline coraz lepiej rozumiem innych mówiących w języku obcym & $85 \%$ \\
\hline znam dużo słówek w danym języku & $75 \%$ \\
\hline potrafię porozumieć się z obcokrajowcami & $50 \%$ \\
\hline poznaję nowych ludzi & $45 \%$ \\
\hline mam coraz lepszą wymowę & $40 \%$ \\
\hline nie boję się mówić w języku obcym & $25 \%$ \\
\hline uzyskuję coraz lepsze wyniki na kursie & $15 \%$ \\
\hline
\end{tabular}

Tabela 2: Co sprawia Pani/Panu największą satysfakcję w nauce języka obcego?

W kolejnym pytaniu respondenci podawali, w jaki sposób wykorzystuja wiedzę językową nabytą w czasie kursu. Najczęściej wskazywano na porozumiewanie się z obcokrajowcami podczas podróży $(75 \%)$. Trzydzieści procent badanych wskazało, że moga pomagać własnym dzieciom w nauce. Pozostałe odpowiedzi pojawiały się pojedynczo, były to: poznawanie obcokrajowców w internecie, możliwość awansowania w pracy, słuchanie piosenek obcojęzycz- 
nych, oglądanie filmów w obcym języku, czytanie obcej literatury. Jedna z badanych podała, że wykorzystuje język, by porozumiewać się z wnukami.

Odpowiadając na czwarte pytanie, dorośli wymieniali rodzaje zadań, jakie najbardziej lubią wykonywać w trakcie zajęć językowych (por. tabela 3). Zaskakująco, 95\% badanych wymieniło czytanie ze zrozumieniem. Najmniej popularne okazało się odgrywanie ról, na które wskazały tylko dwie osoby. Autor badania, podobnie jak w poprzednich pytaniach, podał kilka opcji wyboru oraz zostawił miejsce na wymienienie innych odpowiedzi. Nikt z badanych nie dodał jednak żadnych innych zadań.

\begin{tabular}{|l|c|}
\hline czytanie ze zrozumieniem & $95 \%$ \\
\hline tłumaczenie zdań & $70 \%$ \\
\hline ćwiczenie słuchania ze zrozumieniem & $70 \%$ \\
\hline głośne czytanie & $50 \%$ \\
\hline ćwiczenia gramatyczne & $40 \%$ \\
\hline piosenki & $35 \%$ \\
\hline pisanie dialogów & $25 \%$ \\
\hline
\end{tabular}

Tabela 3: Jakiego rodzaju zadania najbardziej lubi Pani/Pan wykonywać?

Piąte pytanie dotyczyło największych trudności w nauce języka obcego. Odpowiedzi były zróżnicowane, największa ilość odpowiedzi (50\%) dotyczyła jednak braku czasu. Dwadzieścia pięć procent respondentów wymieniło również wstyd przed mówieniem w języku obcym. Zbyt trudną wymowę języka obcego i niezrozumiałość poleceń w podręczniku wskazało odpowiednio po $20 \%$ badanych. Pozostałe odpowiedzi wymieniane były pojedynczo: zbyt szybkie tempo zajęć, uważam, że jestem za stara/y na naukę, nie rozumiem gramatyki, nauczyciel mówi głównie po polsku, za dużo osób w grupie, uczę się wolniej niż kiedyś.

Ostatnie, szóste pytanie było pytaniem otwartym, w którym zapytano respondentów o propozycje zmian ulepszających kurs językowy. $\mathrm{Na}$ to pytanie odpowiedzi udzieliło jedynie osiem osób. Wśród nich proponowano zwiększenie ilości ćwiczeń słuchania ze zrozumieniem i czytania na głos, ćwiczeń komunikacyjnych i zabaw słownych. Postulowano również o szybsze tempo zajęć. Ogólnie, uczestnicy kursów wyrazili swoje zadowolenie z lekcji języka obcego i przyznali, że poświęcają za mało czasu na naukę w domu. Wyrażono również potrzebę prywatnych konwersacji w języku obcym.

\subsection{Opinie nauczycieli}

Druga część badania stanowiły nieformalne rozmowy przeprowadzone przez autora z nauczycielami grup dorosłych. Odbyto je przed rozpoczęciem zajęć, w czasie których nauczyciele przekazali ankiety uczniom. Pytania postawione nauczycielom były podobne do tych z ankiety; autor pytał o opinie nauczycieli dotyczące powodów, dla których dorośli podejmują naukę, źródeł największej satysfakcji z nauki języka, ulubionych typów zadań i największych trudności w naucza- 
niu dorosłych. Nauczyciele ci zgodnie stwierdzili, że początkowo motywacja wśród kursantów była bardzo wysoka, ale z czasem wielu z nich zrezygnowało z kursu. Ci, którzy zaprzestali nauki, najczęściej usprawiedliwiali to natłokiem innych obowiązków lub niepasującymi im terminami, kiedy odbywał się kurs. Nikt nie skarżył się na zbyt wysoki poziom zajęć lub za szybkie ich tempo.

Zapytani o własne obserwacje dotyczace tego, co najwyraźniej motywuje ich uczniów, badani nauczyciele wskazywali na możliwość zrozumienia słów piosenek, sloganów reklamowych (które często pojawiają się w językach obcych), nazw produktów oraz na uczestnictwo w kursie jako sposób spędzenia wolnego czasu. Część kursantów była zmotywowana faktem, że może pomóc własnym dzieciom w nauce języka obcego i podkreślali, że w ten sposób sami rozumieja język lepiej. Badani nauczyciele podawali również wiele przykładów pojedynczych uczniów, którzy dzielili się z nimi własnymi doświadczeniami związanymi z nauką języka. I tak, dla kursantów motywująca była umiejętność przetłumaczenia obcojęzycznego zwrotu (np. widzianego na czyjejś koszulce), zrozumienia napisów na opakowaniu kosmetyku lub przeczytania uproszczonej wersji książki (tzw. „reader”). Jak podkreślali nauczyciele, sama świadomość ucznia, że ,już tyle umiem powiedzieć po angielsku/niemiecku” była istotna zachętą do dalszej nauki.

\section{Wnioski końcowe}

Podsumowując powyższe rozważania i badanie, należy przede wszystkim stwierdzić, że u badanej grupy dorosłych zaobserwowano bardzo wysoką motywację do nauki języków obcych. Choć podawali oni różne powody, dla których podjęli naukę języka, żaden $z$ nich nie wskazywał na jakikolwiek zewnętrzny przymus (np. polecenie pracodawcy, egzamin na studiach), a zatem była to dobrowolna decyzja. Jest to sytuacja bardzo komfortowa dla nauczyciela, którego główną przecież rola jest podnoszenie motywacji wśród uczniów. W przypadku badanych grup, ważnym zadaniem dla nauczyciela będzie, zatem podtrzymywanie tej wewnętrznej motywacji.

Obserwując wyniki badania widzimy, że dorośli podejmują naukę języka obcego przede wszystkim, aby porozumiewać się w czasie podróży. Wydaje się to zrozumiałe, zwłaszcza biorąc pod uwage wzrost zainteresowania Polaków podróżami do obcych krajów. Wskazuje to na orientację integracyjna; coraz większe otwarcie Polaków na obce kultury związane jest z zainteresowaniem nauką języków obcych. Dodatkowo, znajomość języka obcego zaspokaja potrzebę niezależności. Drugim powodem podawanym przez zainteresowanych oraz przez ich nauczycieli była chęć zrozumienia obcojęzycznych piosenek i filmów. Dorośli chcą aktywnie uczestniczyć w życiu kulturalnym, a w zalewie wytworów obcych kultur (głównie anglojęzycznych) brak znajomości języka może spychać poniekąd na margines. W takich przypadkach nierozumienie słów piosenek, nazw produktów, zwrotów obcego pochodzenia (np. deal, leasing, czy 
upgrade) rodzi poczucie wykluczenia. Do nauki języka motywuje, więc szansa lepszego zrozumienia świata. Niemal połowa badanych zwróciła również uwagę na to, że ich rodzina i znajomi posługują się językiem obcym. Emigracja zarobkowa młodych Polaków prowadzi do sytuacji, w jakiej znalazła się jedna z badanych, gdzie jej wnuczek wychowywany w Anglii, nie potrafi płynnie posługiwać się językiem polskim. Osoba ta uczy się języka angielskiego, aby w przyszłości móc z nim porozmawiać. Kolejnym czynnikiem, dla którego badani podjęli naukę była chęć spędzenia wolnego czasu. Ta odpowiedź, wskazana przez 40\% respondentów, pokrywa się z tym, co zaobserwowali badani nauczyciele, tj. część dorosłych przychodzi na kurs głównie w celach towarzyskich. Nauka języka zaspokaja ich potrzebę bycia wśród ludzi, zwłaszcza w gronie rówieśników, gdzie mogą wymieniać swoje poglądy i czuć się docenieni; jest więc to specyficzny motyw integracyjny.

Odpowiedzi na drugie pytanie dotyczące źródeł satysfakcji z nauki języka również pokrywały się z tym, co zaobserwowali badani nauczyciele. Dla większości osób coraz lepsza znajomość języka obcego jest sama w sobie czynnikiem motywującym. Jest to ważna wskazówka dla nauczycieli, którzy chca podtrzymywać motywację swoich uczniów. Częste uświadamianie kursantom jak wiele już osiągnęli to ważny czynnik podtrzymujący ich zapał do nauki.

Wśród ulubionych zadań wymienianych przez dorosłych, przeważająca większość wskazała na czytanie ze zrozumieniem. Może to wskazywać na preferowanie niejako „namacalnych” dowodów, że robi się postęp. Dorośli wskazywali również, że lubią tłumaczyć zdania na język polski, choć stoi to w sprzeczności ze współczesną myśla glottodydaktyczną promującą podejście komunikacyjne. Ponadto, badani rzadko wskazywali na odgrywanie ról, jako ich ulubione ćwiczenie. Wskazuje to na swego rodzaju obawę przed nieskrępowanym używaniem języka obcego, być może traktowanego, jako coś abstrakcyjnego. Rozmowy z nauczycielami również potwierdziły, że dorośli czują się o wiele pewniej w sytuacji, gdy mogą obce zwroty napisać, zanim je powiedza, a każde nowe słowo czy zwrot chcą tłumaczyć na język polski. Popełnianie błędów, choć zupełnie naturalne, zwłaszcza na początku nauki, jest dla wielu dorosłych bardzo deprymujące, dlatego boją się ,eksperymentować” z językiem i nie angażują się z łatwością w zadania komunikacyjne, preferując słowo pisane, kiedy mają więcej czasu na zastanowienie się nad wypowiedzią.

Przeprowadzona ankieta i wywiady ograniczyły się do relatywnie małej próby, stąd wyników badania nie można rozciąnnąć na cała populację. Mimo to pewne zaobserwowane tendencje są z pewnością znamienne dla dorosłych uczących się języka. Przede wszystkim, mówiąc o motywacji dorosłych nie sposób nie wspomnieć o ich różnych potrzebach, jakie nauka języków zaspokoja: potrzebie przynależności do grupy, rozwijania własnych zainteresowań (co umożliwia znajomość języka), potrzebie wyzwań intelektualnych, poznawania obcych kultur i odnoszenia sukcesu. Ponadto, dorośli będąc naturalnie poza obowiązkiem szkolnym, przejawiają wysoką motywację wewnętrzną. Naukę podejmują z własnej 
woli, a w rezultacie ich motywacja na początku kursu jest zwykle wysoka. Należy również zwrócić uwagę na typy zadań, do których wykonania dorośli są zmotywowani bardziej niż do innych. Jak pokazała analiza ankiety, większą popularnością cieszą się zadania związane z recepcją niż produkcją języka.

\section{BIBLIOGRAFIA}

Arnold, J. i Brown, H. D. 2005. „A map of the terrain” (w:) Affect in language learning (red. J. Arnold) Cambridge: Cambridge University Press: 1-24.

Brown, H. D. 1990. „M\&Ms for the language classroom? Another look at motivation" (w:) Georgetown University Round table on languages and linguistics (red. J. E. Alatis) Washington, DC: Georgetown University Press.

Chomsky, N. 1988. Language and problems of knowledge. Cambridge, MA: MIT Press.

Dörnyei, Z. 1990. „Conceptualizing motivation in foreign language learning”. Language Learning 40: 45-78.

Dörnyei, Z. 1994. „Motivation and motivating in the foreign language classroom". Modern Language Journal 78: 273-284.

Dörnyei, Z. 2003. Questionnaires in second language research. Mahwah, NJ: Lawrence Erlbaum.

Figarski, W. 2003. Proces glottodydaktyczny w sqkole. Warszawa: Wydawnictwa Uniwersytetu Warszawskiego.

Gardner, R. C. i Lambert, W. 1972. Attitudes and motivation in second language learning. Rowley, MA: Newbury House.

Gardner, R. C. i MacIntyre, P. D. 1993. „A student's contribution to second language learning. Part II: affective variables". Language teaching 26: 1-11.

Humphreys, G. i. Spratt, M. 2008. „Many languages, many motivations. A study of Hong Kong students' motivation to learn different target languages". System 36: 607-623.

Knowles, M. S., Holton III, E. F. i Swanson, R. A. (red.) 2009. Edukacja dorostych. Warszawa: PWN.

Lankiewicz, H. A. 2010. Foundations of second language acquisition. From theory to language pedagogy. Piła: Państwowa Wyższa Szkoła Zawodowa.

Marczuk, M. 1994. „Próba określenia andragonicznego modelu procesu kształcenia dorosłych" (w:) Problemy $i$ dylematy andragogiki (red. M. Marczuk). Lublin-Radom: UMCS.

Maslow, A. 2006. Motywacja i osobowość. Warszawa: Wydawnictwo Naukowe PWN.

Michońska-Stadnik, A. 2008. „Pojęcie motywacji - wczoraj, dziś i jutro” (w:) Nowe spojrzenia na motywacje w dydaktyce jezyków obcych. Tom 1. (red. A. Michońska-Stadnik i Z. Wassik). Wrocław: Wydawnictwo Wyższej Szkoły Filologicznej we Wrocławiu: 107-117.

Oxford, R. 2007. „Language learning strategies” (w:) Teaching English to speakers of other languages (red. R. Carter i D. Nunan) Cambridge: Cambridge University Press: 166-173. 
Weiner, B. 1985. „An attributional theory of achievement, motivation and emotion". Psychological Review 92: 548-573.

Wilczyńska, W i Michońska-Stadnik, A. 2010. Metodologia badań w glottodydaketyce. Wprowadzenie. Kraków: Avalon.

Williams, M. i Burden, R. L. 2007. Psychology for language teachers. Cambridge: Cambridge University Press.

Zawadzka, E. 2004. Nauczyciele jezylków obych w dobie przemian. Kraków: Impuls. 